\title{
Compositional Characterization of Biosurfactant Produced from Pseudomonas aeruginosa ENO14-MH271625 and its Application in Crude Oil Bioremediation
}

\author{
Ekramul Haque ${ }^{1, *}$, Mohd Aamir Bin Riyaz², Sriram Shankar', Saqib Hassan ${ }^{1}$ \\ 'Department of Microbiology, School of Life Sciences, Pondicherry University, Puducherry, INDIA. \\ ${ }^{2}$ Department of Chemistry, School of Physical, Chemical and Applied Sciences, Pondicherry University, Puducherry, INDIA.
}

\begin{abstract}
Objectives: This study aimed to compositionally characterize the biosurfactant and its application in crude oil bioremediation. Methods: Production of biosurfactant was carried out in Bushnell Hass Broth (BHB), supplemented with $1 \%$ glucose. Compositional characterizations were performed by ${ }^{1} \mathrm{H}-\mathrm{NMR}$ and ESI-MS analysis. The biodegradation of crude oil was carried out by using a $0.1 \%(\mathrm{~g} / \mathrm{v})$ of purified biosurfactant (ENO14BS). The experiment has three sets namely Set A, Set B and Set C. The experiments are as follows: Set A contained $50 \mathrm{ml}$ sterilized BHB medium with bacterial cells (5\% v/v, O.D. $\left.{ }_{600} \sim 1.0\right), 2 \%(\mathrm{v} / \mathrm{v})$ of crude oil and ENO14BS $(0.1 \% \mathrm{w} / \mathrm{v})$. Set B contained $50 \mathrm{ml}$ of sterilized BHB medium with bacterial cells $\left(5 \% \mathrm{v} / \mathrm{v}, \mathrm{O} \mathrm{D}_{600 \mathrm{~nm}} \sim 1.0\right)$ and $2 \%(\mathrm{v} / \mathrm{v})$ of crude oil. Set $\mathrm{C}$ (abiotic control) contained $50 \mathrm{ml}$ of sterilized BHB with $2 \%(\mathrm{v} / \mathrm{v})$ of crude oil only. This experiment was performed for 7 days. Results: Structural elucidation by NMR and Electrospray Ionization-Mass Spectroscopy (ESIMS) showed the presence of six uncommon rhamnolipid homologs, $\mathrm{m} / \mathrm{z}$ (mass to charge ratio) $=358.98[\mathrm{M}+\mathrm{H}]^{+}$, Rha- $_{12: 2^{2}} ; \mathrm{m} / \mathrm{z}=391.28[\mathrm{M}+\mathrm{H}]^{+}$,
\end{abstract}

Rha $-\mathrm{C}_{6}-\mathrm{C}_{6} ; m / z=427.38[\mathrm{M}+\mathrm{H}]^{+}$, Rha- $\mathrm{C}_{17 \cdot 3} ; m / z=447.32[\mathrm{M}+\mathrm{H}]^{+}$, Rha- $\mathrm{C}_{8}-$ $\mathrm{C}_{8} ; \mathrm{m} / \mathrm{z}=507.22[\mathrm{M}+\mathrm{H}]+$, Rha-Rha- $\mathrm{C}_{12: 1} ; \mathrm{m} / \mathrm{z}=648.17[\mathrm{M}+\mathrm{H}]^{+}$, Rha-Rha$\mathrm{C}_{10}-\mathrm{C}_{10: 1}$. The application of biosurfactant (ENO14BS) in biodegradation of crude oil was performed at a laboratory scale. The biosurfactant $(0.1 \%$ $\mathrm{w} / \mathrm{v}$ ) amended microcosm showed up to $73 \%$ crude oil degradation (31\% higher than with culture alone) in four days. Conclusion: We conclude that ENO14BS biosurfactant produced by Pseudomonas aeruginosa ENO14 using glucose in this study has shown its potential for use in the crude oil bioremediation process.

Keywords: Rhamnolipid, NMR, ESI-MS, Crude oil, Bioremediation.

Correspondence

Mr. Ekramul Haque

Senior Research Fellow (SRF), Department of Microbiology, School of Life

Sciences, Pondicherry University, Puducherry-605014, INDIA.

Email: hekramul37@gmail.com

DOI: 10.5530/ijpi.2021.2.36

\section{INTRODUCTION}

The Petroleum industry is considered one of the central and fastest growing industrial sectors. Petroleum and its by-products consist of a complex composition of hydrocarbons and environmental concerns such as oil spills and leakages cause serious havoc to the natural ecosystem and biosphere due to their mutagenic, immunotoxic, carcinogenic and neurotoxic properties. ${ }^{1,2}$ Restoration of such condition is carried out naturally through micro-organisms which can degrade and clean up the toxic pollutants present at petroleum contaminated sites and also for enhanced oil recovery from reservoirs. ${ }^{3-6}$ Such bioremediation strategies for environmental restoration are favoured over conventional physiochemical strategies due to their cost effective and eco-friendly characteristics. ${ }^{7,8}$ Moreover, Microbial degradation is considered as the ultimate natural process for restoring natural conditions in petroleum contaminated areas. ${ }^{9}$ For instance, the notable role of indigenous microbes has been documented in bioremediation/biodegradation mechanisms. ${ }^{10,11}$ Furthermore, hydrocarbon degradation involves various groups of organisms such as fungi, algae and bacteria. ${ }^{12,13,2}$ They are ubiquitous ranging from soil, freshwater and marine habitats. ${ }^{4}$ However, bacteria possess an array of bioactive agents that play a significant role in degrading petroleum as well as in microbial enhanced oil recovery (MEOR) process by producing biosurfactants. Also, such bioactive compounds have significant commercial importance. ${ }^{14-17}$ Moreover, Varjani and Upasani, ${ }^{6}$ have reported the applicability of rhamnolipid biosurfactant produced from an efficient hydrocarbon degrading Pseudomonas sp. in MEOR process. Furthermore, various studies have highlighted the importance of bioremediation by biodegradation as the most influential and effective strategy for eliminating hydrocarbon contaminants from the environment. ${ }^{18,9}$ In this study, we have compositionally characterized the biosurfactant and used it for crude oil bioremediation on laboratory scale.

\section{MATERIALS AND METHODS}

\section{Bacterial strain and cultivation}

Biosurfactant producing $P$. aeruginosa ENO14 was isolated from crude oil contaminated seawater of Ennore, Tamilnadu, India. Culture condition of this isolate has been described earlier. ${ }^{19}$

\section{Production and purification of Biosurfactant}

Production, recovery and purification of biosurfactant was carried out as per the protocol described by Haque et al. ${ }^{20}$ The purified biosurfactant (ENO14BS) was used for further compositional characterization and crude oil bioremediation.

\section{Nuclear magnetic resonance (NMR) spectroscopy analysis}

NMR spectra $\left({ }^{1} \mathrm{H} \mathrm{NMR}\right)$ of the ENO14BS solution were measured at room temperature using a Bruker DRX Advance $400 \mathrm{MHz}$ spectrometer. Twenty-five milligrams of purified ENO14BS sample (dissolved in $1 \mathrm{ml}$ of $99.8 \% \mathrm{CDCl}_{3}$ ) was used for the analysis. ${ }^{21}$ 
ESI-MS (Electrospray lonization Mass Spectrometry) analysis

Biosurfactant mixtures (various congeners, structural analog) present in the purified sample ENO14BS was identified by ESI-MS (Agilent 6530 B QTOF). $50 \mu \mathrm{l}$ of the purified ENO14BS, ( $1 \mathrm{mg} / \mathrm{ml}$ in acetonitrile) was applied into the column. Acetonitrile-water $(1: 1)$ was used as mobile phase for this analysis. The flow rate of HPLC was $0.2 \mathrm{ml} / \mathrm{min}$ and directly applied to the spectrometer. Mass spectrometric condition was as follow: Gas temperature $300^{\circ} \mathrm{C}$, Capillary voltage $3500 \mathrm{~V}$, Fragments voltage $175 \mathrm{~V}$, Nebulizer flow rate $8 \mathrm{ml} / \mathrm{min}$. Mass spectrometer was operating on positive mode (ESI+) and the ionization method was used over the mass range of $50-800 \mathrm{~m} / \mathrm{z}$.

\section{Biodegradation of crude oil in laboratory scale Preparation of inoculum}

The bacterium (Pseudomonas aeruginosa ENO14) was used for the degradation of crude oil. A loop full bacterial culture was added into a mixture of sterilized Bushnell-Hass Broth (BHB, $50 \mathrm{ml}$ ) and crude oil $(0.1 \%, \mathrm{v} / \mathrm{v})$ in a $100 \mathrm{ml}$ conical flask. Then the flask was incubated at $37^{\circ} \mathrm{C}$ overnight at $100 \mathrm{rpm}$. Next day, the broth was centrifuged at $10000 \mathrm{rpm}$ for $5 \mathrm{~min}$ to get the pellet. Finally, the pellet was dissolved in BHB to make O.D. ${ }_{600}$ around 1.0. ${ }^{22}$ This inoculum was used for the degradation study. The crude oil was obtained from S.J. Oils Company, Pondicherry, India and has been used throughout the study.

\section{Extraction of residual crude oil}

BHB medium containing crude oil and bacterial culture was transferred to a separating glass funnel. $20 \mathrm{ml}$ mixture of petroleum ether: acetone (1:1) was added into the medium. ${ }^{23}$ The above process was repeated twice. The mixture of petroleum ether and acetone should be added to the empty flask in order to remove all oil adhered to walls of conical flasks. Then the funnel was vigorously shaken for few minutes and the mixture was poured into empty $50 \mathrm{ml}$ centrifuge tube tubes. The tubes were centrifuged at $8000 \mathrm{rpm}$ at $4^{\circ} \mathrm{C}$ for $15 \mathrm{~min}$. Finally, the organic layer was collected using a pipette and transferred in pre-weighed glass beaker. The beaker containing organic solvent was kept at $50^{\circ} \mathrm{C}$ in a hot air oven to evaporate acetone and petroleum ether. After the solvent evaporation, the residual crude oil was obtained and beaker was weighed. The empty weight of the glass beaker was subtracted to get the amount of residual oil.

\section{Experimental set up for biodegradation}

The experiment was carried out for the biodegradation of crude oil by using a $0.1 \%(\mathrm{~g} / \mathrm{v})$ of purified biosurfactant (ENO14BS). The experiment has three sets namely Set A, Set B and Set C. The experiments are as follows: Set A contained $50 \mathrm{ml}$ sterilized BHB medium with bacterial cells (5\% v/v, O.D. $\left.{ }_{600} \sim 1.0\right), 2 \%(\mathrm{v} / \mathrm{v})$ of crude oil and ENO14BS $(0.1 \%$ $\mathrm{w} / \mathrm{v})$. Set $\mathrm{B}$ contained $50 \mathrm{ml}$ of sterilized BHB medium with bacterial cells ( $5 \% \mathrm{v} / \mathrm{v}$, O.D. $\left._{600 \mathrm{~nm}} \sim 1.0\right)$ and $2 \%(\mathrm{v} / \mathrm{v})$ of crude oil. Set C (abiotic control) contained $50 \mathrm{ml}$ of sterilized BHB with $2 \%(\mathrm{v} / \mathrm{v})$ of crude oil only. All the sets were prepared in triplicate. This experiment was performed for 7 days. Every $24 \mathrm{~h}$ interval the oil was extracted from one flask of each set by above standardized extraction method. Abiotic control (Set C) was maintained to assess the natural weathering of crude oil and it was estimated as $\sim 3.5 \%$ and the value was subtracted from the data obtained in other experimental sets (Set A and B).

Finally, \% of crude oil degradation was calculated following the formula proposed by Ganesh and Lin. ${ }^{24}$
Weight of crude oil extracted from abiotic control

following the formula proposed by Ganesh and L $\%$ degradation of crude oil $=\frac{\text { Original weight of crude oil introduced }}{2}$ $\times 100$

\section{Statistical Analysis}

All the experiments were performed in triplicates and the values were given as mean \pm standard deviation (SD) using Microsoft Excel 2010 (Microsoft, USA).

\section{RESULTS}

\section{Nuclear magnetic resonance (NMR) spectroscopy analysis}

The chemical structures of ENO14BS were analysed by ${ }^{1} \mathrm{H}$ NMR and the results are shown in Figure 1. The chemical shifts at $0.88 \mathrm{ppm}$ indicates the protons of $\left(-\mathrm{CH}_{3}\right)$ of 3-hydroxyacyl fatty acids $\left(\mathrm{FA}^{\mathrm{I}}\right.$ and $\mathrm{FA}^{\mathrm{II}}$, FA stand for fatty acid). The signal at $1.24-1.30 \mathrm{ppm}$ detected the presence of a linear alkane $\left(-\mathrm{CH}_{2}\right)$ of fatty acids $\left(\mathrm{FA}^{\mathrm{I}}\right.$ and $\left.\mathrm{FA}^{\mathrm{II}}\right)$. The chemical shifts at $2.42,4.02$ and $2.16 \mathrm{ppm}$ showed the presence of $\mathrm{H}-2^{\mathrm{r}}, \mathrm{H}-3^{\mathrm{r}}$ and $\mathrm{H}-4^{\mathrm{I}}$ in $\mathrm{FA}^{1}$ respectively. The signal at 2.61, 4.26 and $2.36 \mathrm{ppm}$ indicates the presence of $\mathrm{H}-2^{\mathrm{r}}, \mathrm{H}-3^{\mathrm{I}}$ and $\mathrm{H}-4^{\mathrm{I}}$ in $\mathrm{FA}^{1 \mathrm{II}}$ respectively. The signal at 5.26$5.32 \mathrm{ppm}$ indicates the presence of unsaturated bond in the fatty acids linked to rhamnose molecule. The anomeric proton $\left(\mathrm{H}-1^{\mathrm{I}}\right.$ and $\left.\mathrm{H}-\mathrm{1}^{\mathrm{II}}\right)$ for the rhamnose molecule ( $\mathrm{L}-\mathrm{Rha}^{\mathrm{I}}$ and $\mathrm{L}-\mathrm{Rha}^{\mathrm{II}}$, Rha stand for rhamnose) was observed at 4.88 and $4.72 \mathrm{ppm}$ respectively. The chemical shifts at $3.64,3.51,3.49,3.29 \mathrm{ppm}$ indicates the presence of $\mathrm{H}-2^{\mathrm{I}}, \mathrm{H}-3^{\mathrm{I}}, \mathrm{H}-4^{\mathrm{I}}, \mathrm{H}-5^{\mathrm{I}}$ in $\mathrm{L}-\mathrm{Rha}^{\mathrm{I}}$ respectively. The signal at $3.79,3.65,3.40,3.29 \mathrm{ppm}$ indicates the presence of $\mathrm{H}-2^{\mathrm{II}}, \mathrm{H}-3^{\mathrm{II}}, \mathrm{H}-4^{\mathrm{II}}, \mathrm{H}-5^{\mathrm{II}}$ in $\mathrm{L}-\mathrm{Rha}^{\mathrm{II}}$. The chemical shifts at 1.25 ppm showed the presence of $\mathrm{H}-6^{\mathrm{I}}\left(\mathrm{CH}_{3}\right)$ and $\mathrm{H}-6^{\mathrm{II}}\left(\mathrm{CH}_{3}\right)$ in $\mathrm{L}-\mathrm{Rha}^{\mathrm{I}}$ and L-Rha ${ }^{\mathrm{II}}$.

\section{ESI-MS (Electrospray lonization Mass Spectrometry)} analysis

The structural identification by ESI-MS of ENO14BS produced by P. aeruginosa ENO14 showed the presence of at least six uncommon rhamnolipid homologs. These six prominent peaks were observed at $\mathrm{m} / \mathrm{z} 358.98, \mathrm{~m} / \mathrm{z} 391.28, \mathrm{~m} / \mathrm{z} 427.38, \mathrm{~m} / \mathrm{z} 447.32, \mathrm{~m} / \mathrm{z} 507.22$ and $\mathrm{m} / \mathrm{z}$ 648.17 (Figure 2). The probable $m / z=358.98[\mathrm{M}+\mathrm{H}]^{+}$, Rha-C12:2; $m / z$ $=391.28[\mathrm{M}+\mathrm{H}]^{+}$, Rha-C6-C6; $m / z=427.38[\mathrm{M}+\mathrm{H}]^{+}$, Rha-C17:3; $m / z$

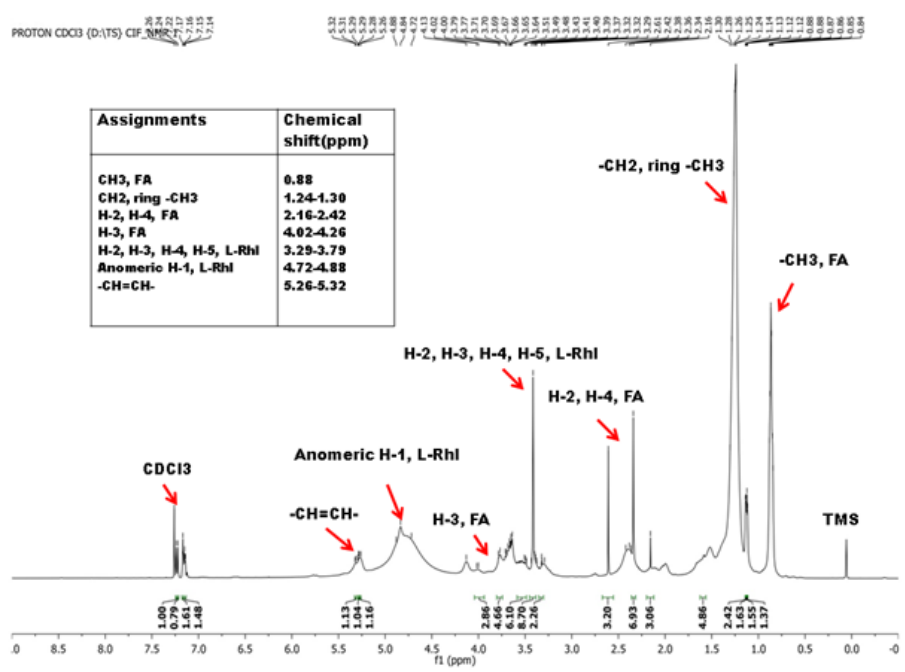

Figure 1: NMR $\left({ }^{1} \mathrm{H}\right)$ spectrum of the biosurfactant ENO14BS showing the presence of various types of protons. 
$=447.32[\mathrm{M}+\mathrm{H}]^{+}$, Rha-C8-C8; $m / z=507.22[\mathrm{M}+\mathrm{H}]^{+}$, Rha-Rha-C12:1; $m / z=648.17$, Rha-Rha-C10-C10:1. The structure of the rhamnolipid homologs are depicted in the Figure 3.

\section{Biodegradation of crude oil in laboratory scale}

In the bioremediation study, the maximum biodegradation, $73 \%$ and $42 \%$ of crude oil was observed in the set $\mathrm{B}(\mathrm{BHB}+$ bacterial cells + crude oil + ENO14BS) and set A (BHB + bacterial cells + crude oil) respectively just after four days of incubation. The highest difference in biodegradation levels between sets B and set A was $31 \%$ after four days (Figure 4). Therefore, this finding indicates that the ENO14BS acts as a very good inducer or enhancer for the bacterial cells for the process of crude oil bioremediation. The degradation of crude oil was decreased in the later stage. This may be the reason for the depletion of nutrients faced by cells. Cells with biosurfactant rapidly utilize oil and minerals for growth and get depleted in later stages.

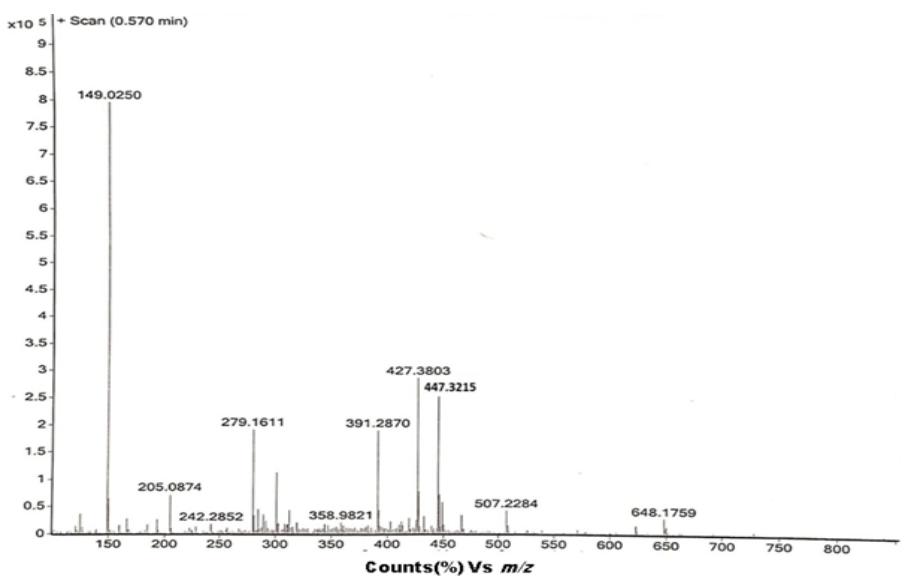

Figure 2: ESI-MS analysis of the purified biosurfactant ENO14BS depicting the molecular mass of different rhamnolipid homologs.
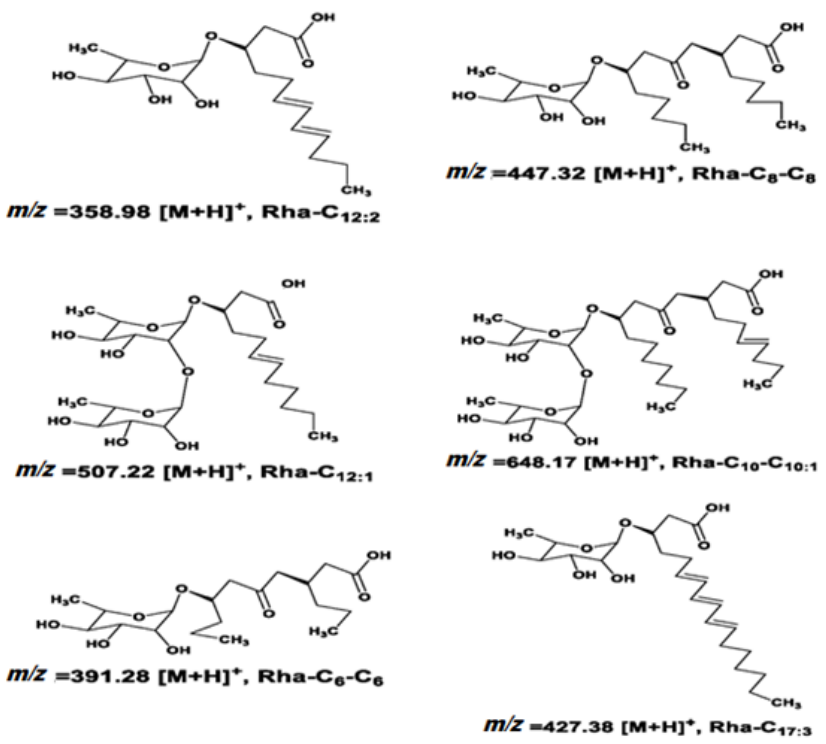

Figure 3: Structure of the six rhamnolipid homologs detected in the purified ENO14BS through ESI-MS.

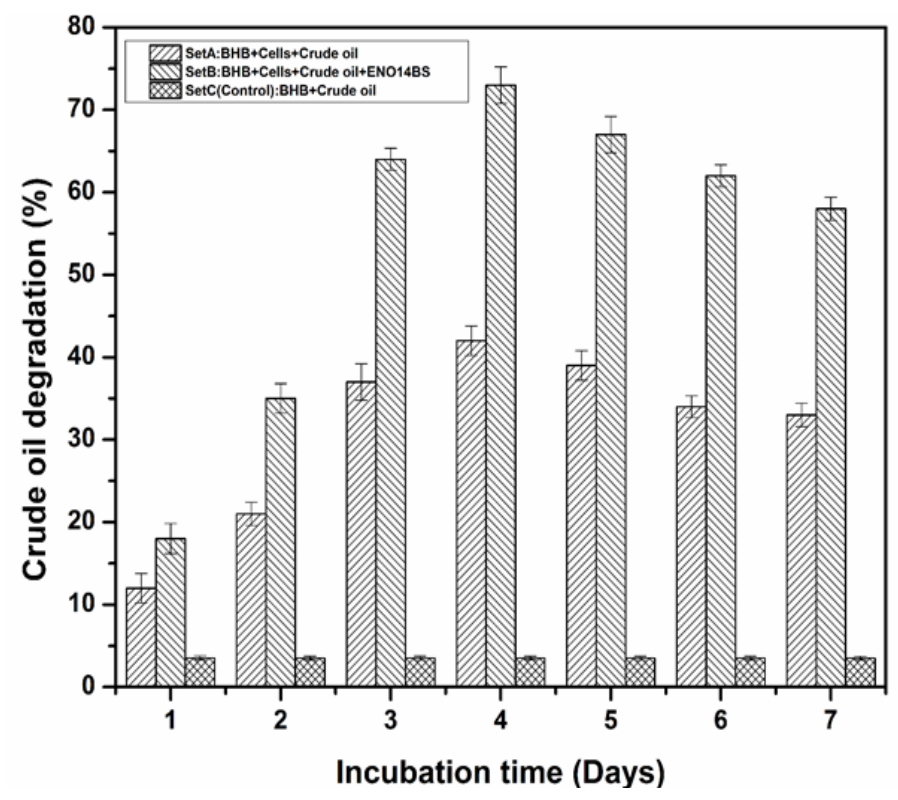

Figure 4: Biodegradation of crude oil by Pseudomonas aeruginosa ENO14 in laboratory scale microcosm experiments. All the analysis was carried out in triplicate. The values were presented as mean \pm SD $(n=3)$.

\section{DISCUSSION}

The Petrochemical industry is considered one of the fastest growing industrial sectors in India. Petroleum and its by-products consist of a complex composition of hydrocarbons and environmental concerns such as oil spills and leakages cause serious havoc to the natural ecosystem and biosphere due to their mutagenic, carcinogenic and neurotoxic properties. ${ }^{1,2}$ Microbial degradation is considered the ultimate natural process for restoring natural conditions in petroleum contaminated areas. ${ }^{9}$ The surface-active molecules play a vital role in the degradation process. Therefore, structural identification of biosurfactant is very crucial to understand the degradation process.

In this study, ${ }^{1} \mathrm{H}$ NMR spectrum was in accordance with the findings observed by other researchers, which clearly shows that the ENO14BS biosurfactant is a mixture of mono-rhamnolipid and di- rhamnolipid attached with saturated or unsaturated fatty acids. ${ }^{25-28}$ ESI-MS analysis of biosurfactant also suggested the presence of various rhamnolipid molecules. Therefore, it can be summarized that $P$. aeruginosa ENO14 strain produced a mixture of both mono and di-rhamnolipids by utilizing glucose as a primary carbon source. Based on the previous literature different strain of Pseudomonas aeruginosa is known to produce mono and di-rhamnolipids mixture under natural condition. ${ }^{29-31}$ In this investigation, the bacterial strain ENO14, in presence of biosurfactant (ENO14BS) showed remarkably higher degradation of crude oil compared to many recent reports on microbial crude oil degradation. ${ }^{32}$ As the biosurfactant was added in the broth, it makes the degradation process faster by increasing the bioavailability of substrate by emulsification and facilitating the association of substrate with bacterial cells by the reduction of cell surface hydrophobicity. ${ }^{33}$ Hence, our result evidently showed that ENO14BS $(0.1 \%, w / v)$, a mixture at least six uncommon mono and di-rhamnolipids, is one of the important factors to enhance the crude oil degradation along with bacterial cells in a very short period.

\section{CONCLUSION}

We conclude that ENO14BS biosurfactant produced by Pseudomonas aeruginosa ENO14 using glucose in this study has shown its potential for 
use in the bioremediation process. Most importantly, in the degradation process, the broth supplemented with ENO14BS enhances the crude oil degradation along with bacterial cells in a very short time. Therefore, hydrocarbon degrading properties of this organism in the presence of biosurfactant have also suggested its application to the in-situ bioremediation of sites polluted by petroleum hydrocarbon as well as the management of oil spills, whether marine or terrestrial. The ENO14BS biosurfactant, composed of six uncommon rhamnolipids can also find applications in cosmetics, mining of minerals, pharmaceutical, food and textile industries after specific sectoral research.

\section{ACKNOWLEDGEMENT}

The author, Ekramul Haque is grateful to UGC, New Delhi for the Maulana Azad National Fellowship. (Award Letter No. F1-17.1/2014-15/ MANF-2014-15-MUS-WES-48033 / (SAIII/ Website).

\section{CONFLICT OF INTEREST}

All the authors declare that there is no conflict of interest

\section{ABBREVIATIONS}

BHB: Bushnell Hass Broth; NMR: Nuclear magnetic resonance; ESIMS: Electrospray Ionization Mass Spectrometry; $\mathbf{C D C l}_{3}$ : Deuterated chloroform.

\section{REFERENCES}

1. Atlas RM. Microbial degradation of petroleum hydrocarbons: An environmental perspective. Microbiol Rev. 1981;45(1):180-209.

2. Tiwari B, Manickam N, Kumari S, Tiwari A. Biodegradation and dissolution of polyaromatic hydrocarbons by Stenotrophomonas sp. Bioresour Technol. 2016;216:1102-5.

3. Lal B, Khanna S. Degradation of crude oil by Acinetobacter calcoaceticus and Alcaligenes odorans. J Appl Bacteriol. 1996;81(4):355-62.

4. Batista SB, Mounteer AH, Amorim FR, Totola MR. Isolation and characterization of biosurfactant/bioemulsifier-producing bacteria from petroleum contaminated sites. Bioresour Technol. 2006;97(6):868-75.

5. Sajna KV, Sukumaran RK, Gottumukkala LD, Pandey A. Crude oil biodegradation aided by biosurfactants from Pseudozyma sp. NII 08165 or its culture broth. Bioresour Technol. 2006;191:133-9

6. Varjani, SJ, Upasani VN. Core flood study for enhanced oil recovery through ex-situ bioaugmentation with thermo- and halo-tolerant rhamnolipid produced by Pseudomonas aeruginosa NCIM 5514. Bioresour Technol. 2016;220:175-82.

7. Balba MT, Al-Awadhi N, Al-Daher R. Bioremediation of oil-contaminated soil: Microbiological methods for feasibility assessment and field evaluation. J Microbiol Methods. 1998;32(2):155-64

8. Das K, Mukherjee AK.Crude petroleum-oil biodegradation efficiency of Bacillus subtilis and Pseudomonas aeruginosa strains isolated from a petroleum oil contaminated soil from North-East India. Bioresour Technol. 2007;98(7):133945.

9. Tanti B, Buragohain AK. Biodegradation of petroleum tar by Pseudomonas spp. from oil field of Assam, India. Biorem J. 2007;17(2):107-12.

10. Goswami P, Singh HD. Different modes of hydrocarbon uptake by two Pseudomonas species. Biotechnol Bioeng. 1991;37(1):1-11.

11. Varjani SJ, Upasani VN. Characterization of hydrocarbon utilizing Pseudomonas strains from crude oil contaminated samples. Int J Sci Comput. 2012;6(2):120-7.

12. Chaillan F, LeFleche A, Bury E, Phantavong YH, Grimont P, Saliot $A$, et al. Identification and biodegradation potential of tropical aerobic hydrocarbon- degrading microorganisms. Res Microbiol. 2004;155(7):587-95.

13. Matsui T, Yamamoto T, Shinzato N, Mitsuta T, Nakano K, Namihira T. Degradation of oil tank sludge using long-chain alkane-degrading bacteria. Ann Microbiol. 2013;64(1):391-5.

14. Banat IM. Biosurfactants production and possible uses in microbial enhanced oil recovery and oil pollution remediation: A review. Bioresour Technol. 1995;51(1):1-12

15. Nalini S, Parthasarathi R. Biosurfactant production by Serratia rubidaea SNAU02 isolated from hydrocarbon contaminated soil and its physico-chemical characterization. Bioresour Technol. 2013;147:619-22.

16. Varjani, SJ, Rana DP, Jain AK, Bateja S, Upasani VN. Synergistic ex-situ biodegradation of crude oil by halotolerant bacterial consortium of indigenous strains isolated from on shore sites of Gujarat, India. Int Biodeterior Biodegrad. 2015;103:116-24.

17. Zhao F, Zhou JD, Ma F, Shi RJ, Han SQ, Zhang J, et al. Simultaneous inhibition of sulfate-reducing bacteria, removal of $\mathrm{H} 2 \mathrm{~S}$ and production of rhamnolipid by recombinant Pseudomonas stutzeri Rhl: Applications for microbial enhanced oil recovery. Bioresour Technol. 2016;207:24-30

18. Leahy JH, Colwell R. Microbial degradation of hydrocarbons in the environment. Microbiol Rev. 1990;4(3):305-15

19. Haque E, Hassan S. Physiochemical Characterization and Anti-colon Cancer Activity of Biosurfactant Produced from Marine Pseudomonas sp. Int J Pharm Investig. 2020;10(2):136-40.

20. Haque E, Kayalvizhi K, Hassan S. Biocompatibility, Antioxidant and Anti-Infective Effect of Biosurfactant Produced by Marinobacter litoralis MB15. Int J Pharm Investig. 2020;10(2):172-7.

21. Pereira JF, Gudiña EJ, Dória ML, Domingues $M R$, Rodrigues $L R$, Teixeira JA, et al. Characterization by electrospray ionization and tandem mass spectrometry of rhamnolipids produced by two Pseudomonas aeruginosa strains isolated from Brazilian crude oil. Eur J Mass Spectrom. 2012;18(4):399-406.

22. Shahaby AF, Alharthi AA, El-Tarras AE. Bioremediation of Petroleum Oil by Potential Biosurfactant-Producing Bacteria using Gravimetric Assay. Int J Cur Microbiol App Sci. 2015;4(5):390-403.

23. Hassanshahian M, Emtiazi G, Cappello S. Isolation and characterization of crude-oil-degrading bacteria from the Persian Gulf and the Caspian Sea. Mar Pollut Bull. 2012;64(1):7-12.

24. Ganesh A, Lin J. Diesel degradation and biosurfactant production by Grampositive isolates. Afr J Biotechnol. 2009;8(21).

25. Sharma D, Ansari MJ, Al-Ghamdi A, Adgaba N, Khan K, Pruthi V. Biosurfactant production by Pseudomonas aeruginosa DSVP20 isolated from petroleum hydrocarbon-contaminated soil and its physicochemical characterization. Environ Sci Pollut Res. 2015;22(22):17636-43.

26. Price NP, Ray KJ, Vermillion K, Kuo TM. MALDI-TOF mass spectrometry of naturally occurring mixtures of monorhamnolipids and dirhamnolipids. Carbohydr Polym. 2009;344(2):204-9

27. Raza ZA, Khalid ZM, Banat IM. Characterization of rhamnolipids produced by a Pseudomonas aeruginosa mutant strain grown on waste oils. J Environ Sci Health. 2009;44(13):1367-73.

28. Monteiro SA, Sassaki GL, DeSouza LM, Meira JA, DeAraújo JM, Mitchell DA Molecular and structural characterization of the biosurfactant produced by Pseudomonas aeruginosa DAUPE 614. Chem Phys Lipids. 2007;147(1):1-13.

29. Nie M, Yin X, Ren C, Wang Y, Xu F, Shen Q. Novel rhamnolipid biosurfactants produced by a polycyclic aromatic hydrocarbon-degrading bacterium Pseudomonas aeruginosa strain NY3. Biotechnol Adv. 2010;28(5):635-43.

30. Abdel-Mawgoud AM, Lépine F, Déziel E. Rhamnolipids: Diversity of structures, microbial origins and roles. Appl Microbiol Biotechnol. 2010;86(5):1323-36.

31. Patowary R, Patowary K, Kalita MC, Deka S. Utilization of paneer whey waste for cost-effective production of rhamnolipid biosurfactant. Appl Biochem Biotechnol. 2016;180(3):383-99.

32. Sathishkumar M, Binupriya AR, Baik SH, Yun SE. Biodegradation of crude oil by individual bacterial strains and a mixed bacterial consortium isolated from hydrocarbon contaminated areas. CLEAN-Soil Air Water. 2008;36(1):92-6.

33. Mulligan CN, Gibbs BF. Types, production and applications of biosurfactants. Proceedings-Ind Nat Sci Acad. Part B. 2004;70(1):31-56.

Article History: Submission Date : 11-10-2020; Revised Date : 19-12-2020; Acceptance Date : 01-04-2021.

Cite this article: Haque E, Riyaz MAB, Shankar S, Hassan S. Compositional Characterization of Biosurfactant Produced from Pseudomonas aeruginosa ENO14-MH271625 and Its Application in Crude Oil Bioremediation. Int. J. Pharm. Investigation, 2021;11 (2):204-7. 